\title{
The Use of Muskox Kill Sites as Temporary Rendezvous Sites by Arctic Wolves with Pups in Early Winter
}

\author{
DAVID R. GRAY ${ }^{1}$
}

\author{
(Received 25 November 1991; accepted in revised form 23 August 1993)
}

\begin{abstract}
Packs of arctic wolves, Canis lupus arctos, travelling with pups were seen in August or September in Polar Bear Pass, Bathurst Island, Northwest Territories, in five of eight years of field observations. One pack with five pups was observed in 1977 over a period of 19 days. The activity of the pack was centred around the sites of two recently killed muskoxen. Adults took pups to a new kill only the day after the kill but did regurgitate meat for them within 2 hours. Adults and pups continued to use kill sites for up to 8 days after depletion of food available at the carcass. Pups were left on their own at the sites for 8-55 hours at a time. The pups travelled without adults between the kill sites and up to $5 \mathrm{~km}$ away at rates varying from 2.5 to $10 \mathrm{~km}^{\cdot \mathrm{h}^{-1}}$. Pups travelled as fast as $11 \mathrm{~km} \cdot \mathrm{h}-1$ over longer distances when with adults. The observed time of extensive travel with the pack was earlier than for most southern wolves. The use of kills as temporary rendezvous sites after the pack has begun travelling provides not only a place to meet, but allows pups to rest, feed,
\end{abstract} explore, and gain experience while adults continue hunting.

Key words: wolf, Canis lupus arctos, development of pups, rendezvous sites, homesites, muskoxen (Ovibos moschatus), Polar Bear Pass, Bathurst Island, Northwest Territories

RÉSUMÉ. Pendant 5 des 8 années durant lesquelles on a mené des observations sur le terrain, dans la vallée Polar Bear, située dans l'île de Bathurst (Territoires du Nord-Ouest), on a aperçu des bandes de loups arctiques, Canis lupus arctos, se déplaçant avec des louveteaux durant les mois d'août et de septembre. En 1977, on a observé une bande avec 5 louveteaux durant 19 jours. Les activités de la bande gravitaient autour des sites où se trouvaient les cadavres de 2 boeufs musqués récemment tués. Les adultes ont emmené les louveteaux auprès d'une nouvelle proie seulement le jour après l'avoir abattue, mais ils ont régurgité la viande pour leurs petits dans les 2 heures qui ont suivi la mort de l'animal. Les adultes et les petits ont continué d'utiliser l'emplacement où les proies avaient été tuées jusqu'à 8 jours après avoir consommé toute la viande. Les louveteaux étaient laissés à eux-mêmes sur les sites pour des durées allant de 8 à 55 heures d'affilée. Ils se déplaçaient sans les adultes entre les sites où se trouvaient les carcasses et jusqu'à $5 \mathrm{~km}$ de ces sites, à des vitesses allant de 2,5 à $10 \mathrm{~km} \cdot \mathrm{h}^{-1}$. Ils pouvaient atteindre $11 \mathrm{~km} \cdot \mathrm{h}^{-1}$ sur de longues distances, lorsqu'ils se déplaçaient avec des adultes. Le moment où les louveteaux ont commencé à se déplacer sur de longues distances avec la bande est arrivé plus tôt que chez les loups vivant plus au sud. En plus d'offrir un point de rencontre temporaire après que la bande a commencé à se déplacer, le lieu où se trouvent les carcasses est un site où les louveteaux peuvent se reposer, se nourrir, explorer et acquérir de l'expérience pendant que les adultes continuent de chasser.

Mots clés : loup, Canis lupus arctos, développement des louveteaux, points de rencontre, base, boeuf musqué (Ovibos moschatus), vallée Polar Bear, île Bathurst, Territoires du Nord-Ouest

Traduit pour le journal par Nésida Loyer.

\section{INTRODUCTION}

Gray wolf (Canis lupus Linnaeus) pups leave their summer homesites (densites or rendezvous sites) sometime in the fall or early winter and join the adults in their hunting activities (Mech, 1970). The time of homesite abandonment is probably correlated with the pups' physical development (Van Ballenberghe et al. , 1975; Fritts and Mech, 1981; Harrington and Mech, 1982a). Wolf pups in Minnesota use summer homesites until August and sometimes into early November. After they leave and begin regular travel with the pack, they may return to preferred summer rendezvous sites, presumably due to difficulty in keeping up with pack movements (Harrington and Mech, 1982a). Packs in Jasper National Park in Alberta often return during winter to summer rendezvous sites close to their hunting areas (Dekker, 1985). From yearround studies in Alaska, Haber (1977) showed that wolf packs with pups use summer rendezvous sites until early or late September, but there is no extensive use of homesites once the pups begin their travels with the pack. Haber concluded that the need to maintain homesites is dictated by the pups' inability to travel continuously with the pack until they are 4-5 months old. For packs on Baffin Island, Northwest Territories (N.W.T.), which face the hardships of winter much earlier than temperate-region wolves, Clark (1971) found that pups leave the summer den sites and begin their travels with adults by mid-August.

The wolves of Canada's High Arctic, where winter begins in early September, range over territories of up to $900 \mathrm{~km}^{2}$ (Riewe, 1975). Little is known of the winter ecology of arctic wolves, especially the participation of pups in pack activities after leaving homesites. Recent studies on Ellesmere Island, N.W.T., show that young arctic wolves may follow adults while hunting at 10 weeks of age (Packard et al., 1992) but use rendezvous sites relatively close to the natal den at least until the end of August, when they are about 13 weeks old (Mech, 1988, 1991). Gray (1983, 1987) described interactions between muskoxen (Ovibos moschatus) and arctic wolf packs in September that included several observations of pups accompanying packs during these encounters. Grace (1976) found that pups from a local den near the Eureka weather station on Ellesmere Island continued to spend long periods at the station dump in mid-winter and that both the dump and the den site were part of the pack's usual winter foraging range.

This paper describes the behaviour of arctic wolf packs with pups in early winter on Bathurst Island and, in particular,

\footnotetext{
${ }^{1}$ Canadian Museum of Nature, P.O. Box 3443, Station D, Ottawa, Ontario, Canada K1P 6P4; present address: Grayhound Information Services, R.R. 3, Metcalfe, Ontario, Canada K0A 2 P0

(C)The Arctic Institute of North America
} 
the pups' participation in pack activities centred on two muskox kills. The apparent use of recent kills as new temporary rendezvous sites by packs travelling with pups after leaving summer homesites, as described here, increases our understanding of the concept of rendezvous sites and suggests their possible importance in the winter ecology of arctic wolves.

\section{MATERIALS AND METHODS}

Observations of wolves were made as part of a study of the behaviour of muskoxen (Gray, 1987) at Polar Bear Pass, Bathurst Island, N.W.T., between 1968 and 1979 and during related studies between 1984 and 1991. Behavioural observations of muskoxen and incidental observations of wolves were made throughout July, August, and September in 6 years between 1970 and 1977, in October of 1970 and 1971, and throughout the winter of 1970-71. Observations were also made from June to mid-September in 1990 and 1991.

The study area consists of approximately $140 \mathrm{~km}^{2}$ of high arctic tundra surrounding the Canadian Museum of Nature's High Arctic Research Station at $75^{\circ} 43^{\prime} \mathrm{N}, 98^{\circ} 25^{\prime} \mathrm{W}$ (Fig. 1). The tundra vegetation in the study area ranges from wet sedge meadows on the floor of the pass to rocky polar desert on the rolling hills that bound the area on the north and south.

At Bathurst Island, winter (that period of the year during which the mean daily temperature remains below $0^{\circ} \mathrm{C}$ ) begins about 25 August and ends about 15 June (Maxwell, 1981).
September is characterized by mean temperatures below $0^{\circ} \mathrm{C}$ (mean max. $-2.7^{\circ} \mathrm{C}$, mean min. $-7.8^{\circ} \mathrm{C}$ ), winds averaging $19.3 \mathrm{~km} \cdot \mathrm{h}^{-1}$, frequent periods of ice fog, and a moderate snow cover beginning early in the month.

Almost all observations were made from the research station's observation tower at distances of $50 \mathrm{~m}$ to $5 \mathrm{~km}$, using Bushnell spotting scopes $(20 \times 60 \mathrm{~mm})$ and a Zeiss $60 \mathrm{~mm}$ zoom binocular telescope. To simplify the description of wolf activity, seven categories were used, generally following the terminology of Mech $(1970,1991)$. "Resting" includes all postures associated with immobility, including lying, sitting, and sleeping. "Travelling" includes walking, trotting, and galloping unrelated to predation or play. "Exploration" refers to olfactory, tactile, or visual investigation. "Hunting" includes all aspects of prey catching from initial orientation through approach, chase, and attack and includes waiting near prey between approaches. "Social behaviour" refers to social contacts and communication between individual wolves, including greeting and howling. "Playing" consists of patterns that have serious purpose in other circumstances, such as fighting, escape, or prey catching, but appear in "non-serious," spontaneous contexts. "Feeding" refers to all activities associated with the ingestion of food, including eating from regurgitate or scavenging from a carcass.

When all pack members were not engaged in the same activities at the same time, the activity recorded was the one

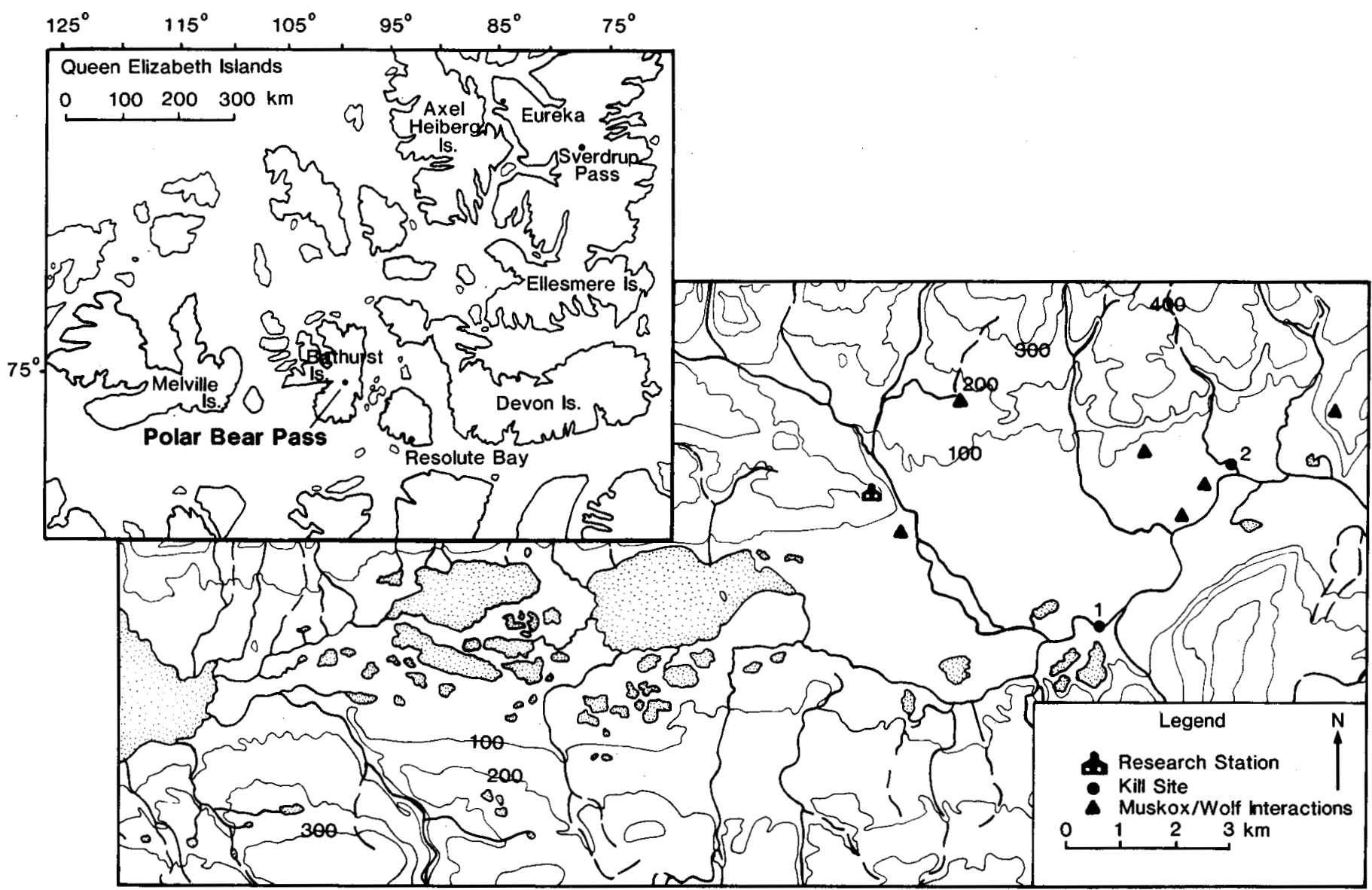

FIG. 1. The study area at Polar Bear Pass showing location of 1977 muskox kill sites and interactions between wolf pack and muskox herds. 
engaged in by at least half of the wolves visible. This simplification was used because the numbers of wolves present was variable and the observation distance and weather conditions made reliable identification of individuals impossible. Activity of the wolves could be determined at distances up to $10 \mathrm{~km}$ in good light and weather conditions.

Observers did not approach or howl to the wolves and visited the kill sites only once. Estimates of travel rates are based on map measurements in conjunction with known landmarks. Observations were restricted to the hours of daylight and twilight (from 24 hours of daylight in late August to 13 hours of daylight and 4 of twilight in late September).

\section{RESULTS}

In all 8 years when observations extended through September, wolves without pups were seen in each month from June to September. Packs with 2-5 pups were seen in August or September in 5 of the 8 years (Table 1). Pups were not seen in October. The two earliest observations of pups travelling with packs were on 11 August 1991 (male, female, and 3 pups) and 6 September 1973 (male, female, and 4 pups).

No wolf dens were found on limited helicopter or fixedwing aircraft reconnaissance flights made over much of Bathurst Island during the period of the study. The only wolf denning areas on Bathurst Island known to Inuit hunters from Resolute Bay are on the southwestern and southern parts of the island (Riewe, 1976), 40 and $75 \mathrm{~km}$ from the study area. Three pups with two aduits were seen about $40 \mathrm{~km}$ from Polar Bear Pass near one reported den area on 10 August 1984 (Reed, pers. comm. 1984). Infrequent and irregular observations of adult wolves and no observations of pups during the summer months (Table 1) support our assumption that there were no dens near the study area.

Except for 1977, packs with pups were known to have been in the study area for only brief periods of up to 30 hours. However, in 1977, a pack of 10 wolves (including 5 pups) was in the study area for at least 19 days, from 11 to 29 September. Detailed behavioural observations were made on 12 days for a total of 30 hours.

The activities and movements of the 1977 pack, and especially the pups, centred on two sites at which the wolves had apparently killed bull muskoxen (Fig. 1). Although neither kill was observed, it is unlikely that either bull died of other causes, as each had been in the area for at least one week and appeared to be in good condition.

The 10 wolves were first seen in the study area on 11 September but were only noticed at the first kill site on
20 September. In the riverbed at the site were the head and rib cage of a bull muskox, most likely a solitary bull last seen there on 10 September and probably killed that day. The kill was buried and frozen under $3 \mathrm{~m}$ drifts of new, wet snow on 21 September. Following the loss of the carcass, the pack continued to use this site for 8 days. The area most used by the wolves was just above the kill on the flat, sparsely vegetated edge of the riverbank, $2-3 \mathrm{~m}$ above the river and $5 \mathrm{~km}$ from the research station.

The second site was $4 \mathrm{~km}$ from the first in a small gully leading down to the river. On 20 September a solitary bull muskox approached a herd of 13 muskoxen but left after intensive displays by the herd's dominant bull. As the solitary bull reached the gully, fog obscured the area. When the fog cleared 1.5 hours later, we saw the adult wolves move from a new carcass in the gully to the pups at the first site. When we visited the second kill 5 days later, the wolves had removed the hide and almost completely stripped the meat from the carcass. Most of the wolf tracks and beds were in the snow of the gully around the kill rather than up on the surrounding flats.

In the 10 days from our discovery of the two kill sites until the wolves left the area (29 September), the pups were observed using the two sites almost equally (site 1,27 hours, 44 minutes; site 2, 22 hours, 12 minutes) and used both of the sites on 5 of the 10 days (Table 2). Adult wolves were also present at both sites on 5 days, but they were observed at the second site almost twice as much as at the first (site 1, 9 hours, 36 minutes; site 2, 18 hours, 3 minutes). Although the pack often split and some pups accompanied adults while others stayed at or returned to kill sites, pups were never seen at both sites at the same time. Adults left the pups during the day for at least 6 hours on 24 September and 8 hours on 25 September. No adults were seen and all were assumed to be away for 55 hours from 1100 on 27 September to 1700 on 29 September, when one adult returned and led the pups away.

\section{ACTIVITY PATTERNS AND BEHAVIOUR}

For the packs and pups observed in years other than 1977, the activities of the wolves during the short periods of observation were mostly travelling, with some hunting, resting, and exploration. For the 1977 pack, resting, travelling, and exploration were the main activities associated with the kill sites. The behaviour patterns observed in these high arctic wolf pups at the beginning of their first winter are much the same as those reported for southern wolf populations (Mech, 1970).

TABLE 1. Date of first sighting of wolf pups each year in relation to other sightings and length of observation period

\begin{tabular}{|c|c|c|c|c|c|c|}
\hline Year & Start of obs. period & $\begin{array}{l}\text { Last obs. of wolves } \\
\text { without pups (no. of wolves) }\end{array}$ & $\begin{array}{l}\text { First obs. of pups } \\
\text { (no. of pups) }\end{array}$ & $\begin{array}{l}\text { Other obs. of pups } \\
\text { (no. of pups) }\end{array}$ & Last obs. of pack & End of obs. period \\
\hline 1970 & 11 April & 12 Sept. (2) & 16 Sept. (2) & 28 Sept. (1) & 28 Sept. & 31 Dec. \\
\hline 1973 & 18 April & 26 Aug. (3) & 6 Sept. (4) & 13 Sept. (4) & 13 Sept. & 25 Sept. \\
\hline 1976 & 1 April & 28 July (2) & 8 Sept. (4) & 16 Sept. (4) & 16 Sept. & 4 Oct. \\
\hline 1977 & 17 May & 16 Aug. (2) & 11 Sept. (5) & 12-29 Sept. (5) & 29 Sept. & 2 Oct. \\
\hline 1991 & 15 June & 8 Aug. (1) & 11 Aug. (3) & 28 Aug. (3) & 28 Aug. & 14 Sept. \\
\hline
\end{tabular}


TABLE 2. Number of minutes pups and adults were observed at each of two muskox kill sites in 1977 on Bathurst Island, N.W.T.

\begin{tabular}{|c|c|c|c|c|c|c|c|c|c|c|c|}
\hline & \multicolumn{10}{|c|}{ Date in September } & \multirow[b]{2}{*}{ Total } \\
\hline & 20 & 21 & 22 & 23 & 24 & 25 & 26 & 27 & 28 & 29 & \\
\hline \multicolumn{12}{|c|}{ Site 1: Adult male muskox killed probably 10 or 11 September. Carcass unavailable after 21 September. } \\
\hline $\begin{array}{c}\text { Pups } \\
\text { Adults }\end{array}$ & $\begin{array}{l}329 \\
175\end{array}$ & $\begin{array}{l}? \\
?\end{array}$ & $\begin{array}{l}90 \\
90\end{array}$ & $\begin{array}{l}120 \\
120\end{array}$ & $\begin{array}{r}80 \\
0\end{array}$ & $\begin{array}{l}15 \\
15\end{array}$ & $\begin{array}{r}280 \\
0\end{array}$ & $\begin{array}{l}710 \\
180\end{array}$ & $\begin{array}{r}35 \\
0\end{array}$ & $\begin{array}{l}5 \\
0\end{array}$ & $\begin{array}{r}1664 \\
576\end{array}$ \\
\hline \multicolumn{12}{|c|}{ Site 2: Adult male muskox killed 20 September. Carcass $90 \%$ utilized by 25 September. } \\
\hline $\begin{array}{c}\text { Pups } \\
\text { Adults }\end{array}$ & $\begin{array}{r}0 \\
275\end{array}$ & $\begin{array}{l}122 \\
157\end{array}$ & $\begin{array}{l}65 \\
65 \\
\end{array}$ & $\begin{array}{l}590 \\
516 \\
\end{array}$ & $\begin{array}{l}0 \\
0\end{array}$ & $\begin{array}{c}180 \\
? \\
\end{array}$ & $\begin{array}{l}70 \\
70 \\
\end{array}$ & $\begin{array}{l}0 \\
0 \\
\end{array}$ & $\begin{array}{l}0 \\
0 \\
\end{array}$ & $\begin{array}{r}300 \\
0 \\
\end{array}$ & $\begin{array}{l}1322 \\
1083 \\
\end{array}$ \\
\hline
\end{tabular}

Note: ? indicates wolf sighted but time spent unknown because of fog or snow. Vertical line indicates loss of food source through drifting of snow at site 1 and depletion of carcass through feeding at site 2 .

\section{Resting}

Resting accounted for $36 \%$ of the time when wolves were under observation. The periods when all pack members were resting together ranged from 3 minutes to over 8.5 hours. Rest periods of over an hour occurred after extensive travel, at dawn, and during or after hunting. The relative inactivity of adult wolves at the kill sites confirms the importance of rendezvous sites as locations for rest as well as for feeding pups (Kolenosky and Johnston, 1967; Murie, 1944).

\section{Travelling}

Travelling (32\%) was the next most frequently observed behaviour. This observation is similar to the findings that wolves in Minnesota in winter (Mech, 1992) and Alaskan wolves (Peterson et al., 1984) spend a large portion of the daytime period (28\% and $30 \%$ respectively) in travel activities.

The pups travelled up to $8 \mathrm{~km}$ from the kills when with adults and up to $5 \mathrm{~km}$ away while on their own. When travelling, the wolves usually moved in single file, with the pups behind the adults. The order of travel among both adults and pups changed, but the pups were almost always last. Pups often required a burst of galloping to catch up to the pack.

The rate of travel varied with the circumstances and the composition of the pack. For example, a single adult leading five pups moved at approximately $8 \mathrm{~km} \cdot \mathrm{h}^{-1}$ when travelling the $4 \mathrm{~km}$ between kills on 25 September 1977. Four days later, four pups, with no adults present, travelled the same route at only $4 \mathrm{~km}^{\cdot \mathrm{h}^{-1}}$. The pups stopped frequently to chase each other, play, howl, lie down, and dig in the snow. Pups on their own, travelling the $5 \mathrm{~km}$ between the research station and the first kill, took 2 hours to cover the distance on 26 September and only 30 minutes on 28 September. The earliest recorded rate of travel for pups was on 28 August 1991 , when three pups with a pair of adults travelled $4 \mathrm{~km}$ across Polar Bear Pass at $6 \mathrm{~km} \cdot \mathrm{h}^{-1}$.

A single pup joined three adults when they left the study area on 27 September and covered $11 \mathrm{~km}$ in the first hour of travelling. The pup had to gallop almost all of the time to keep up as the group travelled a minimum of $16 \mathrm{~km}$ in 2 hours. The adults did not appear to adjust their speed to the pup's and never approached the pup. That pup and the rest of the adults were not seen again. Two days later, one adult returned and led the remaining four pups along what appeared to be the same route. The five wolves covered about $5 \mathrm{~km}$ in 40 minutes of travelling before they disappeared into thick fog.

\section{Exploration}

Exploratory behaviour at the muskox kill sites accounted for $18 \%$ of pack activities, a similar finding to Mech's (1970) that exploratory behaviour is a significant activity at rendezvous sites. While in the area of the kills and during breaks in travelling between them, pups continually sniffed, pawed, and chewed objects or the substrate, including tussocks, muskox skulls, and plastic seismic shot-hole markers (Fig. 2). Although both adults and pups stopped often to investigate objects, for adults such stops consisted of a brief olfactory investigation; the pups' behaviour was more manipulative. Pups also sniffed at or rolled where female and male adults urinated.

\section{Hunting}

Hunting activity constituted $5 \%$ of the pack's observed behaviour. We saw wolves hunting lemmings (Dicrostonyx torquatus) twice, both times while the pack was moving between kill sites. The adult and a single pup used the same technique, rising up on the hind legs and pouncing down with the forepaws together through the snow. Apparently both were unsuccessful.

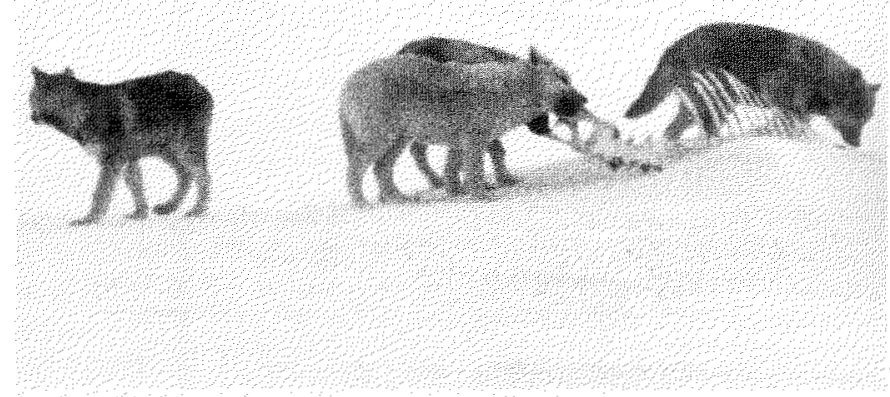

FIG. 2. Four of five pups in the 1977 pack investigating a muskox skeleton near the research station, 25 September 1977. 
After the kill of the lone bull on 20 September, six unsuccessful hunts were directed at muskox herds. During three of these incidents, the pups remained behind at the kill site watching, while the adults approached and attacked a herd less than $2 \mathrm{~km}$ away. In two other encounters, pups accompanied the pack during the approach but stayed away from the herd, sitting and watching the interaction. On 26 September, for example, five adult wolves and two pups approached a herd of 15 muskoxen. The herd ran, then stopped as the wolves darted at two trailing bulls, circling close around them. The pups remained in the background as three wolves attacked the herd as it stampeded. The pups only moved towards the two bulls after the adults had broken off the unsuccessful attack.

Wolf pups also approached muskoxen on two occasions in the absence of adults. On 28 September three pups circled three muskox bulls, moving about $20 \mathrm{~m}$ apart to within $12 \mathrm{~m}$ of the bulls, before steadily but warily walking around to one side and back to the first kill site.

\section{Social Behaviour}

Social behaviour (greeting and howling) accounted for 5\% of observed activities. Greeting (Mech, 1970) by pups was usually seen when adults returned to the pups (seven observations) and after a long period of rest at the site (three observations). Three times when an adult returned from the second kill (twice on the day of the kill and once two days later), the pups jumped all around and over the adult, once knocking it to the ground, nuzzling and nipping at its mouth.

Howling by pups left at a kill was heard only once. When two observers approached the second kill on 25 September, two pups walked from the carcass towards them, watching intently. After they rejoined their three littermates, one of the pups began howling. Then all five moved about $200 \mathrm{~m}$ down the riverbank and howled for 25 minutes, before heading to the first kill site.

When one adult began howling after the pack had ended the attack on the herd of muskoxen on 26 September, the other adults and the two pups joined in the howling. The adults and one of the two pups later howled while facing south towards the kill site where the other three pups were. These three pups, $8 \mathrm{~km}$ from the other wolves, did not respond.

We recorded only three instances of pups howling while away from the kill sites. In each case only a single pup howled, although it was accompanied by three other pups on at least two of these occasions.

\section{Playing}

Bouts of play lasting 1-6 minutes were observed on 15 occasions, accounting for $2 \%$ of the total observation time: eight bouts involved pups only ( $24 \mathrm{~min}$ ), four involved pups and adults $(9 \mathrm{~min})$, and three involved adults only $(15 \mathrm{~min})$. Chasing play on smooth snowdrifts along the riverbed was most common. Both adults and pups jumped and slid down the steeper parts of the riverbanks. Play among pups was not seen away from the sites.

The three bouts of adult-only play occurred while four adults were returning to the pups after three unsuccessful hunting attempts on muskox herds. Each bout lasted 4-6 minutes as the adults chased each other back to the pups. The pups sat watching from the kill, making no move to approach or join the adults. Play was otherwise not seen while wolves were travelling or hunting away from the sites.

The relatively high frequency of both greeting and play observed relates to previous conclusions that meetings at rendezvous sites are positive events, providing reinforcement for site visits by pack members (Mech, 1970; Peterson, 1977; Harrington and Mech, 1982a).

\section{Feeding}

There were three observed food sources for wolf pups at the kill sites: the fresh muskox carcass, meat brought from other kills and regurgitated by adults, and the pups' own minimal hunting. Feeding occupied only $1 \%$ of observation time. However, we were unable to observe either carcass directly, and since tracks indicated that both adults and pups fed extensively on the second carcass, the actual time spent feeding would have been greater.

On 20 September, within an hour of the killing of the second muskox, three adults left the kill and headed towards the pups at the first site. One adult was mobbed by the pups until it regurgitated food. Four hours and 30 minutes after the adults arrived they returned to the new carcass, $4 \mathrm{~km}$ away, leaving all five pups together at the old site. An adult arrived 2 hours later and was mobbed by the pups. This adult left the pups after spending 2 hours and 45 minutes with them and rejoined the other adults. The pups were still at the first site when it became dark at midnight, 1.5 hours later. Our observations the following day were delayed by fog until midday, at which time the pups were seen at the new kill. Thus the pups were taken to the second kill between 11 and 24 hours after the kill took place.

How long adults continue to bring food back and regurgitate it for the growing pups in their first winter is not known, though Mech (1970) suggested that adults will regurgitate for five-month-old and possibly older pups, based on an experimental situation with captive wolves. The observed regurgitation in September suggests that this behaviour continues as long as rendezvous sites are used and pups are left behind while adults hunt.

\section{DISCUSSION}

The use of recent kill sites as areas of rest for pups and as a temporary focal point for the activities of a travelling pack, as described here, indicates that these sites are rendezvous sites in the sense used by previous authors (Murie, 1944; Joslin, 1967; Harrington and Mech, 1982a,b). Previous observations have indicated that kill sites to which young pups have been taken in summer do become rendezvous sites (Young and Goldman, 1944; Mech, 1970). The situation described here where a kill site becomes a new rendezvous site for travelling packs after leaving summer homesites supplements the current concept of rendezvous sites. These kill sites had become more than a source of food as the wolves, particularly the pups, continued to use one site for over a week after the carcass was buried by snow and a 
second kill was available nearby. In contrast, wolves in Alaska remained at kill sites in winter for only about 2-3 days in the period after leaving homesites and moving throughout their territory (Haber, 1977).

Although both pups and adults showed strong attachment to the sites, the difference in their use between adults and pups suggests that it is the pups that have a greater need of the focal point of a known site. However, the ability of adults to relocate pups that lag behind during winter travel would be improved if kill sites became important foci for adults as well. The knowledge of former kill site locations might also facilitate the reunion of wolves travelling seminomadically over wide areas, with the sites acting as nodes within a cognitive map or spatial memory (Peters, 1978). Peters suggested that locations of kills would be among the important elements encoded in the cognitive maps of wolves.

The August and September observations of pups travelling with packs in Polar Bear Pass at a considerable distance (at least $40 \mathrm{~km}$ ) away from the probable den site indicate that high arctic wolf pups likely face the hardships of both the nomadic life and winter at an earlier age than most southern wolves, as Clark (1971) found for Baffin Island wolves.

All of the pups we observed had difficulty in keeping up to the travelling pack, partly due to their exploratory behaviour, but also apparently due to size and stamina. The travel rates we recorded for adults are similar to those reported by Mech $(1966,1970)$ but in some instances, even when pups were with the pack, were considerably higher. The pups' difficulty in keeping up with the pack would be tempered by the use of kill sites as temporary rendezvous sites.

The use of new rendezvous sites by arctic wolves as described parallels the reuse of old summer homesites by other wolves in early winter. Whereas southern wolves can reuse the same sites because of their year-round proximity, arctic wolves, once they begin extensive travel, may not have the option of returning to a familiar summer site because of distance; instead, the use of a new kill as a rendezvous site would achieve the same end. In the same way that studies in Minnesota have indicated the continued importance of summer homesites to the wolf pack during fall and early winter (Harrington and Mech, 1982a), the use of new sites by arctic wolves could be of similar significance in their winter ecology.

The short-term use of newly established rendezvous sites in early winter would enable young arctic wolves to gain strength and experience after they leave the homesites and begin to travel with the adults, while avoiding the hardship of virtually continuous travel. Through observing adult wolves approaching and chasing prey species within visible range of a kill site, as well as by accompanying adults when they begin an attack, pups learn some aspects of hunting, even though at 3-4 months old they are not ready to attack large prey such as muskoxen (Gray, 1987).

By using recent kill sites as temporary rendezvous sites, a pair or small pack could begin ranging over a greater extent of their territory with their pups in early winter. This use would allow wide-ranging travel much sooner after the summer period of more restricted movement in the area near the den than if the adults had to wait for pups to develop speed and endurance to match their own.

\section{ACKNOWLEDGEMENTS}

This paper is a product of the research program in ethology at the Canadian Museum of Nature. Field research was supported logistically by the Polar Continental Shelf Project (Department of Energy, Mines, and Resources). John Morgan and David Gill shared in the field collection of the information presented here. I also gratefully acknowledge the contributions of Heather Duggan, David Gill, and Anne Smithers to the preparation of this paper. I wish to thank Fred Harrington, Stan van Zyll de Jong, and three other reviewers for their helpful and constructive criticisms of an earlier version of this paper.

\section{REFERENCES}

CLARK, K.R.F. 1971. Food habits and behavior of the tundra wolf on central Baffin Island. Ph.D. thesis, University of Toronto, Toronto, Ontario. $223 \mathrm{p}$.

DEKKER, D. 1985. Responses of wolves, Canis lupus, to simulated howling on a homesite during fall and winter in Jasper National Park, Alberta. Canadian Field-Naturalist 99(1):90-93.

FRITTS, S.H., and MECH, L.D. 1981. Dynamics, movements, and feeding ecology of a newly protected wolf population in northwestern Minnesota. Wildlife Monographs 80:1-79.

GRACE, E.S. 1976. Interactions between men and wolves at an arctic outpost on Ellesmere Island. The Canadian Field-Naturalist 90(2):149-156.

GRAY, D.R. 1983. Interactions between wolves and muskoxen on Bathurst Island, Northwest Territories, Canada. Acta Zoologica Fennica 174:255-257.

1987. The muskoxen of Polar Bear Pass. Markham, Ontario: NMNS/Fitzhenry and Whiteside. $191 \mathrm{p}$.

HABER, G.C. 1977. Socio-ecological dynamics of 'wolves and prey in a subarctic ecosystem. Ph.D. thesis, University of British Columbia, Vancouver, British Columbia. 785 p.

HARRINGTON, F.H., and MECH, L.D. 1982a. Fall and winter homesite use by wolves in northeastern Minnesota. Canadian Field-Naturalist 96(1):79-84.

HARRINGTON, F.H., and MECH, L.D. 1982b. Patterns of homesite attendance in two Minnesota wolf packs. In Harrington, F.H., and Paquet, P.C., eds. Wolves of the world: Perspectives of behaviour, ecology and conservation. Park Ridge, New Jersey: Noyes Publications. 81-109.

JOSLIN, P.W.B. 1967. Movements and home sites of timber wolves in Algonquin Park. American Zoologist 7:279-288.

KOLENOSKY, G.B., and JOHNSTON, D.J. 1967. Radio-tracking timber wolves in Ontario. American Zoologist 7:289-303.

MAXWELL, J.B. 1981. Climatic regions of the Canadian Arctic Islands. Arctic 34(3):225-240.

MECH, L.D. 1966. The wolves of Isle Royale. United States National Park Service, Fauna Series No. 7. 210 p. 1970. The wolf: Ecology and behavior of an endangered species. New York: The Natural History Press. 384 p.

. 1988. The arctic wolf; living with the pack. Stillwater, Minnesota: Voyageur Press. $128 \mathrm{p}$.

. 1991. The way of the wolf. Stillwater, Minnesota: Voyageur Press. 120 p.

1992. Daytime activity of wolves during winter in northeastern Minnesota. Journal of Mammalogy 73(3):570-571.

MURIE, A. 1944. The wolves of Mount McKinley. Fauna of the National Parks of the United States. Fauna Series No. 5. Washington, D.C.: United States Government Printing Office. $238 \mathrm{p}$.

PACKARD, J.M., MECH, L.D., and REAM, R.R. 1992. Weaning in an arctic wolf pack: Behavioral mechanisms. Canadian Journal of Zoology 70:1269-1275.

PETERS, R. 1978. Communication, cognitive mapping, and strategy in wolves and hominids. In: Hall, R.L., and Sharp, H.S., eds. Wolf and man: Evolution in parallel. New York: Academic Press. 95-107. 
PETERSON, R.O. 1977. Wolf ecology and prey relationships on Isle Royale. Fauna Series 11. Washington, D.C.: U.S. National Park Service. 210 p. PETERSON, R.O., WOOLINGTON, J.D., and BAILEY, T.M. 1984. Wolves of Kenai Peninsula, Alaska. Wildlife Monographs 88:1-52.

RIEWE, R.R. 1975. The high arctic wolf in the Jones Sound region of the Canadian High Arctic. Arctic 28(3):209-212.

1976. Inuit land use in the high Canadian Arctic. In: Milton Freeman Research Limited. Inuit land use and occupancy project. Vol. 1.
Ottawa: Department of Indian Affairs and Northern Development. 173-187.

YOUNG, S.P., and GOLDMAN, E.A. 1944. The wolves of North America. Dover: New York. $636 \mathrm{p}$.

VAN BALLENBERGHE, V., ERICKSON, A.W., and BYMAN, D. 1975. Ecology of the northern timber wolf in northeastern Minnesota. Wildlife Monographs 43:1-43. 